\title{
Argentina and Brazil: Laws as Mediators of Social Identities
}

\author{
Yussef Daibert Salomão de Campos \\ Juiz de Fora Federal University, Juiz de Fora; \\ Universidade Federal de Pelotas (UFPel), Pelotas, Brazil
}

\begin{abstract}
The research is a brief analysis of recent legislation in Argentina about the intangible heritage and its relationship with Brazilian instruments. This is a study about links between the two laws and their touch points and their differences. It will be seen that the legislative actions follow a common sense but are targeted for different acts of management of cultural heritage. We will be able to observe how legislation, whether it is Argentine or Brazilian, works as a mediator between the reclaiming of heritage (as in the acknowledgement of cultural practices) and the government actions towards cultural heritage. This shows that Argentina, despite not creating specific federal legislation regarding intangible cultural heritage, is aware of the need to preserve the cultural events that belong in this category of heritage.
\end{abstract}

Keywords: law, intangible heritage, Brazil and Argentina

\section{Introduction}

Through the partnership established between Universidade Federal de Pelotas (UFPel) and Universidad de Buenos Aires (UBA) ${ }^{1}$, the author was able to take part in a research internship from June 2010 to September of the same year in Argentina's capital, Buenos Aires. The postgraduate programs involved in this internship were the posgrado en Economia Politica de la Cultura-Estudios sobre Producciones Culturales y Patrimonio de La Facultad de Filosofia y Letras (ICA/FFyL), from the Universidad de Buenos Aires, and the master's degree program in Social Memory and Cultural Heritage from the Universidade Federal de Pelotas/Brazil. We were able to observe how legislation, whether it is Argentine or Brazilian, works as a mediator between the reclaiming of heritage (as in the acknowledgement of cultural practices) and the government actions towards cultural heritage.

Before we can assess the laws from the Ciudad Autonoma de Buenos Aires (CABA), it is appropriate here to make a short analysis of Argentine laws, following legal hierarchy, since Argentina's federative structure is similar to Brazil's.

\section{Laws and Acts}

Argentina's constitution, from 1994, introduced a chapter that brought to light rights and guarantees nonexistent up until then. The second chapter, named Nuevos derechos y garantias, establishes through its

Yussef Daibert Salomão de Campos, Ph.D. candidate, Institute of Human Sciences, Juiz de Fora Federal University; master in Social Memory and Cultural Heritage, Institute of Human Sciences, Universidade Federal de Pelotas (UFPel); CAPES scholarship student.

${ }^{1}$ Programa de cooperación internacional asociado para el fortalecimento de La posgrado-Brasil/Argentina (CAFP/BA), CAPES (Coordenação de Aperfeiçoamento de Pessoal de Nível Superior). 
article 41 that every resident must enjoy the right to a balanced environment, suited for human development, being the government's responsibility to provide this right, as well as to use natural resources rationally and protect natural e cultural heritage.

We highlight the title of the chapter in which the mentioned article falls. However, it is possible to see that the constituent left to the common legislator the duty to develop instruments and legal concepts appropriate to the protection of Argentina's cultural heritage (even including some of UNESCO's (United Nations Organization for Education, Science and Culture) guidelines). This legislative technique proves to be somehow different from the one in Brazil, which has a more comprehensive article (article 216 ${ }^{2}$ ) about the concept of Brazilian cultural heritage and the legal instruments used to ensure its safeguard, protection and promotion.

The federal legislation in Argentina that best describes the intangible cultural heritage is ley 26118, from $2006^{3}$. It is this law that brings to Argentina's legal system UNESCO's 2003 convention on the protection of intangible cultural heritage. There is no specific law on this matter, like the 3,551 Brazilian decree from year 2000: While Brazilian constitution builds instruments—such as the inventory and registry of intangible cultural resources, the national plan of intangible heritage and the obligation of regular reevaluation every 10 years, Argentina's federal law only incorporates UNESCO's convention, a move also made by Brazil, which has edited its law on intangible heritage even before the 2003 convention. It is possible to observe, as we study the CABA legislation, that each law will result in specific action over heritage management, since federal legislation will not do so. But, by adding the 2003 convention to its legal system, Argentina falls under certain regulations, such as the interdependence of tangible and intangible heritage and the need to protect intangible heritage through its proper identification, documentation, investigation, preservation, protection, promotion and appreciation. The country also accepts UNESCO's definition of intangible heritage, described in paragraph one of the 2003 convention:

The "intangible cultural heritage" means the practices, representations, expressions, knowledge, and skills—as well as the instruments, objects, artifacts, and cultural spaces associated therewith—-that communities, groups, and, in some cases, individuals recognize as part of their cultural heritage. (UNESCO, 2003, Retrieved from http://www.unesco.org/culture/ich/index.php?lg=en\&pg=00022\#part1)

This shows that Argentina, despite not creating specific federal legislation regarding intangible cultural heritage, is aware of the need to preserve the cultural events that belong in this category of heritage ${ }^{4}$. As presented earlier, the country leaves to the common legislator the duty of developing management instruments.

At regional level, we can see that Argentina's determinations are also presented in a less specific way,

\footnotetext{
2 "Article 216. The Brazilian cultural heritage consists of the assets of a material and immaterial nature, taken individually or as a whole, which bear reference to the identity, action and memory of the various groups that form the Brazilian society, therein included: I—forms of expression; II—ways of creating, making and living; III—scientific, artistic and technological creations; IV —works, objects, documents, buildings and other spaces intended for artistic and cultural expressions; V—urban complexes and sites of historical, natural, artistic, archaeological, paleontological, ecological and scientific value".(Retrieved from http://www.stf.jus.br/repositorio/cms/portalStfInternacional/portalStfSobreCorte_en_us/anexo/constituicao_ingles_3ed2010.pdf)

${ }^{3}$ Other laws are more specific, such as the one that declares Tango a part of Argentina's cultural heritage (Ley 24684/año de 1996), or the one about the cataloging system of cultural heritage (Ley 25197/año de1999).

4 The "intangible cultural heritage", as defined in paragraph one above, is manifested inter alia in the following domains: (a) oral traditions and expressions, including language as a vehicle of the intangible cultural heritage; (b) performing arts; (c) social practices, rituals and festive events; (d) knowledge and practices concerning nature and the universe; (e) traditional craftsmanship. (Convention for the Safeguarding of Intangible Cultural Heritage, UNESCO 2003, paragraph two).
} 
whilst the Constitution of Minas Gerais establishes, following the guidelines of the Brazilian Constitution, legal concepts and instruments in its article 208. The Constitution of CABA, in its article 32, only determines that the Buenos Aires' government must guarantee preservation, restoration and promotion of cultural heritage, regardless of its legal regime and ownership ${ }^{5}$.

At CABA's common law level, it is possible to see more distinct public actions that work towards seeking effectiveness in the practice of the general determinations ruled by the federal and Ciudad Autonoma's constitutions. The laws chosen to be analyzed are these: ley 130/1999, ley 1227/2004, and 1535/2005. They were selected by a time criterion (all of them were edited after the 1994 constitutional reform and the revision of CABA's constitution in 1996).

The first one of them is known as ley de tango, which acknowledges tango as part of the cultural heritage of Buenos Aires ${ }^{6}$. This law not only promotes the safeguarding, promotion and restoration of cultural assets but also the promotion and encouragement of every artistic, cultural, academic, educational and urban activity related to tango. This is possible because of the partnerships established between the Buenos Aires' government and other institutions, which promote activities involving education and research, such as exhibitions and presentations, both locally and internationally. The mentioned law also rules on creating a general file that gathers all artistic and cultural expressions related to tango, and providing government sponsorship to nonprofit organizations that have similar goals to the ones specified by the law.

The law proves to be in accordance to the international demands raised in the 90s. The 1999 law is the result of many debates regarding the safeguarding of intangible heritage, some of which are the Carta de Mar del Plata and the Carta de Fortaleza, both from 1997; these debates, among others, have had as their most significative outcome the 2003 UNESCO convention. The safeguarding of intangible heritage and its interdependence with tangible heritage were recurrent subjects in the Cartas Patrimoniais and academic discussions. The article eight of the ley de tango is a reflection of it:

The city's government must guarantee the inviolability of the cultural heritage of tango, in regards to symbolic architectural and urban sites. It must also provide the appropriate means for the completion of events and activities that take place in the city's public spaces, in order to shape a particular urban aesthetic based on the imagery of tango. ${ }^{7}$

Meanwhile, the 2004 law number 1,227, known as ley de marco, works as a reference for all the legislation in CABA that aims to create instruments for the management of city's heritage. This law intends to define the range of intangible heritage and conceptualize it. Article four describes which categories are part of CABA's cultural heritage. Among them there is (point “j”):

Intangible expressions and manifestations: the civic culture, which is shaped by the traditions, customs, and habits of the community, as well as spaces or forms of expression of popular and traditional culture of historical, artistic,

\footnotetext{
5 "Art 32 The city distinguishes and promotes all creative activities. (...) This Constitution guarantees the preservation, recuperation and dissemination of cultural heritage memory and history of the city and its neighborhoods, whatever their legal status and ownership are” (Retrieved from http://www.cedom.gov.ar/es/legislacion/institucional/constbsas/index2.html\#ll1).

${ }^{6}$ Tango is recognized as CABA's cultural heritage (ley 130 from 1999), Argentina’s cultural heritage (ley 24,684 from 1996) and has recently been considered by UNESCO an intangible cultural heritage of mankind (2009).

${ }^{7}$ El Gobierno de La Ciudad debe garantizar la intangibilidad Del patrimonio cultural del tango, em lo que respecta a emplazamientos arquitectónicos y urbanísticos emblemáticos. Asimismo contribuirá por los médios apropiados a tareas y actividades tendientes a ambientar espacios públicos de La Ciudad, a fin de plasmar una estética urbana propia a través Del imaginário del Tango (CABA, 1999, Retrieved from www.buenosaires.gov.ar/areas/cultura/cpphc/legislacion.php).
} 
anthropological or linguistic value, current and/or at risk of disappearing ${ }^{8}$.

This definition is aligned with the concept created by the UNESCO convention. Furthermore, it brings a definition noticeably influenced by the UNESCO's experience with the "Living human treasures" program, which proposes that the government should support people or groups that, by themselves, embody culture. Article five determines that the Living Cultural Heritage must be recognized as Patrimonio Cultural de la Ciudad Autonoma de Buenos Aires (PCCABA).

Article 5 Living Cultural Heritage: in a particular category are those people or social groups that, because of their contribution to tradition, in the various manifestations of popular culture, deserve to be considered members of the PCCABA. $^{9}$

Finally, ley 1535/2005 demands the creation of an atlas of CABA's intangible heritage, where safeguarding instruments such as inspection, registration (only as a form of cataloging and not like the Brazilian registration) and inventory. The law also imposes that there should be regular assessments at least every five years, similarly to what the Brazilian decree $3551^{10}$ suggests.

\section{Conclusions}

We may see that there is nothing as specific as the Robin Hood law, from Minas Gerais, that verses about redirecting financial resources gathered from tax collection from the state to its cities. Naturally, we are here observing a sui generis situation, since CABA's condition is comparable to Minas Gerais' in terms of legislation, but not in its condition of state, as part of a federal union. Therefore, there is no point in talking about redirecting funds from CABA to other cities, since CABA is not a state.

However, an analysis on how legislation works as a mediator between social identities and public policies is needed. We notice how Argentina's hierarchically superior laws leave to the "local” lawmakers (CABA's lawmakers) the duty of creating legal instruments which are, in Brazil, created and managed by superior political groups. We may notice as well that the previously analyzed Argentina legislation characterizes heritage, in almost all cases, as "cultural”, and not as "tangible" or "intangible”.

This shows a lot more coherence with the international guidelines (UNESCO) of heritage safeguarding, from the lawmaker's part, while in Brazil there is a constant division of heritage in categories, not only at the moment of creating concepts and classifications (which is acceptable and even necessary to some specific management decisions), but also when it comes to writing laws (that should approach cultural heritage as a whole).

Certainly, Brazil acknowledges the need to preserve the tangible aspects of intangible heritage (as we may see in some of the National Institute of Historical and Artistic Heritage-IPHAN actions, both in the National

\footnotetext{
${ }^{8}$ Expresiones y Manifestaciones Intangibles: de la cultura ciudadana, que estén conformadas por lãs tradiciones, lãs costumbres y los hábitos de La comunidad, así como espacios o formas de expresión de la cultura popular y tradicional de valor histórico, artístico, antropológico o lingüístico, vigentes y/o em riesgo de desaparición (CABA, 2004, Retrieved from www.buenosaires.gov.ar/areas/cultura/cpphc/legislacion.php).

9 “Artículo $5^{\circ}$ Patrimonio Cultural Viviente: Constituyen también una particular categoría, aquellas personas ó grupos sociales que por su aporte a las tradiciones, em las diversas manifestaciones de la cultura popular, ameriten ser consideradas como integrantes del PCCABA” (CABA, 2004, Retrieved from www.buenosaires.gov.ar/areas/cultura/cpphc/legislacion.php).

10 "Article 7-IPHAN shall procceed to the re-assessment of the registered cultural assets, at least every ten years, and shall refer such assessments to the Advisory Board for the Cultural Heritage for decision as to the revalidation of the title of "Cultural Heritage of Brazil” (Retrieved from http://www.unesco.org/culture/natlaws/media/pdf/bresil/brazil_decreto_3551_04_08_2000_eng_tno.pdf)
} 
Inventory of Cultural Reference-INRC, developed by the Intangible Heritage agents, and in resolutions such as 127 , that discusses the interdependence of tangible and intangible heritage connected to the concept of cultural landscape ${ }^{11}$ ), but legislation is still insensitive to these debates.

The point is to not only recognize the tangible aspects of intangible heritage (and vice versa), as it is done in the INRCs, but to also see in these demands to recognize heritage, tangible or intangible, a possibility to shine a light on the many social identities there are inside of it. We are dealing with a conflict zone, where a number of different identities battle themselves; with a land where being protected by public policies on the preservation of cultural heritage decide whether something will be remembered or forgotten.

\section{References}

Anderson, B. (2008). Comunidades Imaginadas (Imagined communities: Reflections on the origin and spread of nationalism). São Paulo: Companhia das Letras.

Argentina. Constitution of Argentina. (1994). Retrieved from www.senado.gov.ar.

Brazil. Federal Constitution. (1988). Retrieved from www.senado.gov.br

Brazil. Minas Gerais. Constituição estadual. (1989). Retrieved from www.almg.gov.br

Brown, M. F. (2005). Heritage trouble: Recent work on the protection of intangible cultural property. International Journal of Cultural Property, 12, 40-61.

Campos, Y. D. S. de. (2013). Percepção do Intangível: entre genealogias e apropriações do patrimônio cultural imaterial (Perception of the Intangible: between genealogies and appropriation of intangible cultural heritage). Belo Horizonte: Arraes Editores.

Campos, Y. D. S. de. (2014). Proposições para o patrimônio cultural (Propositions to cultural heritage). Juiz de Fora: Funalfa.

Clavir, M. (1996). Reflections on changes in museums and the conservation of collections from indigenous peoples. Journal of the American Institute for Conservation, 35(2), 99-107.

Harding, S. (2005). Bonnischsen v. United States: Time, place and the search for identity. International Journal of Cultural Property, 12, 249-263.

Lowenthal, D. (1988). The past is a foreign country. Cambridge: Cambridge University Press.

Lowenthal, D. (1998). The heritage crusade and the spoils of history. Cambridge: Cambridge University Press.

\footnotetext{
11 “Considering the provisions of Decree-Law No. 25, dated November 1937, which organizes the protection of historical and artistic heritage, (...), and Decree No. 3,551, of August 4, 2000, which establishes the registration of cultural assets of an intangible nature, (...), considering that the existing legal instruments that deal with cultural and natural heritage, taken individually, do not completely cover the set of implicit factors in cultural landscapes (...), resolves: to establish the seal of the Brazilian Cultural Landscape, applicable to portions of the national territory” (section of the IPHAN's 127 ordinance).
} 